\title{
Tinjauan Pustaka: Kajian in Vivo dari Obat Luka Kulit Berbahan Acalypha Indica, Aloe Vera, dan Centella Asiatica
}

\author{
Yanto Hindrawan', Rina Priastini Susilowati ${ }^{2}$, Monica Puspa Sari $^{3}$ \\ ${ }^{1}$ Fakultas Kedokteran dan Ilmu Kesehatan, Universitas Kristen Krida Wacana, Jakarta, Indonesia \\ ${ }^{2}$ Departemen Biologi, Fakultas Kedokteran dan Ilmu Kesehatan, Universitas Kristen Krida Wacana, \\ Jakarta, Indonesia \\ ${ }^{3}$ Departemen Parasitologi, Fakultas Kedokteran dan Ilmu Kesehatan, Universitas Kristen Krida Wacana, \\ Jakarta, Indonesia \\ Alamat Korespondensi: yanto.2017fk187@civitas.ukrida.ac.id
}

\begin{abstract}
Abstrak
Luka merupakan gangguan pada sel dan jaringan anatomi yang dapat disebabkan oleh beberapa hal baik disengaja maupun tidak disengaja. Luka terutama pada kulit jika tidak diobati dengan baik maka dapat menimbulkan infeksi. Hal ini disebabkan oleh proses penyembuhan luka yang kompleks dan dinamis. Proses ini memerlukan bantuan berupa obat yang terbuat dari bahan sintesis ataupun alami. Tinjauan pustaka ini ditulis dengan tujuan untuk mengevaluasi kemanjuran tiga tanaman obat yang sering digunakan untuk mengobati luka, yaitu Acalypha indica, Aloe vera, dan Centella asiatica. Penelusuran dan penapisan pustaka di lakukan dengan Proquest, Pubmed dan Google Scholar dengan kata kunci wound healing AND Acalypha indica OR Centella asiatica OR wound healing OR Aloe vera. Sebanyak 25 makalah dipilih untuk penulisan tinjauan pustaka ini. Acalypha indica, Aloe vera, dan Centella asiatica merupakan tanaman obat yang efektif untuk mengobati luka luar. Hal in telah dibuktikan dalam berbagai studi in vivo bahwa ekstrak tanaman herbal ini memiliki efektivitas yang baik untuk menyembuhkan luka dibandingkan obat medis. Penggunaa tanaman herbal untuk pengobatan juga dianggap lebih murah, aman, mudah didapat dan diolah. Acalypha indica, Aloe vera dan Centella asiatica merupakan tanaman obat yang efektif untuk mengobati luka luar.
\end{abstract}

Kata Kunci : efektivitas, luka, proses penyembuhan luka, tanaman herbal

\section{In Vivo Studies of Skin Wound Medicine Made from Acalypha Indica, Aloe Vera, and Centella Asiatica : A Review}

\begin{abstract}
Wounds are an anatomical cell and tissue disorder that can be induced by several causes, either intentionally or unintentionally. Wounds, especially on the skin, can cause infection if not treated properly Wound healing is a complex and dynamic process, which requires treatment whether in the form of synthetic or plant-derived drugs. The purpose of this literature study is to evaluate the effectiveness of three herbal plants that are often used in wound healing, including: Acalypha indica, Aloe vera, Centella asiatica. Literature search and screening were conducted using Proquest, PubMed and Google Scholar search engines, using keywords wound healing AND Acalypha indica OR Centella asiatica OR wound healing OR Aloe vera. 25 paper was chosen for this literature review. In vivo studies have shown that Acalypha indica, Aloe vera, Centella asiatica were effective to heal skin wounds. Further, some herbal plants extracts were more effectiveness than synthetic drugs. Compared to synthetic drugs, medicinal plant extracts have several benefits, including lower cost, safer and easier to obtain. Acalypha indica, Aloe vera, Centella asiatica are effective medicinal plants for skin wound healing.
\end{abstract}

Keywords: effectiveness, herbal plant, wound, wound healing process 


\section{Pendahuluan}

Sebagai organ terbesar dari tubuh manusia, kulit tubuh memiliki persentase $15 \%$ dari total berat badan orang dewasa. Kulit memiliki beberapa fungsi seperti perlindungan fisik serta imunologi, ekskresi, indra, pengaturan suhu tubuh, dan pembentukan vitamin D. ${ }^{1}$ Luka dapat didefinisikan sebagai gangguan pada sel dan jaringan anatomi yang dapat disebabkan oleh beberapa hal baik disengaja maupun tidak disengaja. Pada luka, mikroorganisme lebih mudah masuk ke dalam tubuh manusia sehingga menimbulkan infeksi dan menganggu aktivitas. Proses penyembuhan luka merupakan suatu proses yang sangat kompleks dan dinamis. Proses ini dibagi menjadi tiga fase utama, yaitu: hemostasis dan inflamasi, fase proliferasi dan fase maturasi atau remodeling. ${ }^{2,3}$ Sejak dahulu, manusia telah mengenal berbagai macam tanaman yang dapat digunakan untuk mengobati penyakit. Tanaman herbal merupakan tanaman yang dapat digunakan untuk mengatasi atau menyembuhkan beberapa penyakit dan digunakan sebagai pengobatan alternatif karena biaya yang lebih murah dibandingkan obat sintesis, mudah didapat dan digunakan. Terdapat beberapa tanaman yang digunakan untuk membantu mengobati luka, yaitu: Acalypha indica yang sering dijumpai di berbagai tempat, Aloe vera yang sudah dikenal berbagai khasiatnya dan Centella asiatica yang mulai dikenal terutama dalam bidang kecantikan. ${ }^{2}$

Seiring berjalannya waktu, obat-obatan untuk luka kulit luar berbahan sintesis mulai dikembangkan dan digunakan untuk pengobatan. Obat-obatan untuk luka kulit luar merupakan obat yang memiliki kandungan antimikroba, antiseptik, maupun antibiotik dan dapat membantu proses penyembuhan luka. Beberapa contoh obat yang digunakan misalnya povidion iodine, phosphate buffered saline, dan berbagai jenis antibiotik. ${ }^{5,7}$ Namun, penggunaan yang terus menerus berbagai macam obat terutama antibiotik dapat menimbulkan resistensi dari mikroorganisme sehingga obat tersebut tidak dapat digunakan lagi di masa mendatang. ${ }^{2,5}$ Hal inilah yang menyebabkan mulainya diteliti kembali berbagai tanaman herbal yang memiliki potensi untuk dapat menyembuhkan luka.

Potensi dari tanaman obat inilah yang membuat penulis tertarik untuk mengevaluasi kemanjuran tiga tanaman obat, Acalypha indica, Aloe vera, dan Centella asiatica. Ketiga tanaman ini merupakan tanaman yang sering digunakan sebagai obat luka dan dapat ditemukan di berbagai tempat.

\section{Metodologi}

Tinjauan literatur dilakukan dengan pendekatan deskriptif berdasarkan kepustakaan berupa artikel penelitian yang memiliki tema yang sama. Pencarian artikel dilakukan menggunakan Google schoolar, Proquest dan PubMed dengan kata kunci dan Boolean operator yaitu wound healing AND Acalypha indica OR Centella asiatica OR wound healing OR Aloe vera. Hasil dari pencarian tersebut kemudian disaring dengan kriteria inklusi dan ekslusi. Kriteria inklusi berupa artikel penelitian acalypha indica, aloe vera dan centella asiatica untuk proses penyembuhan pada kulit mencit, dengan waktu publikasi dalam kurun waktu 2010-2020 dan menggunakan bahasa indonesia atau Inggris. Kriteria ekslusi berupa artikel yang datanya tidak jelas, memiliki perbedaan tema, metode yang tidak dijelaskan dengan baik dan yang tidak ditampilkan secara keseluruhan. Hasil dari kriteria ekslusi dan inklusi sebanyak 121 kemudian disaring mandiri dengan membaca manual untuk mendapatkan artikel sesuai kriteria inklusi. Hasil akhir dari pengecekan manual sebanyak 7 buah yang dapat digunakan sebagai studi literatur ini. 


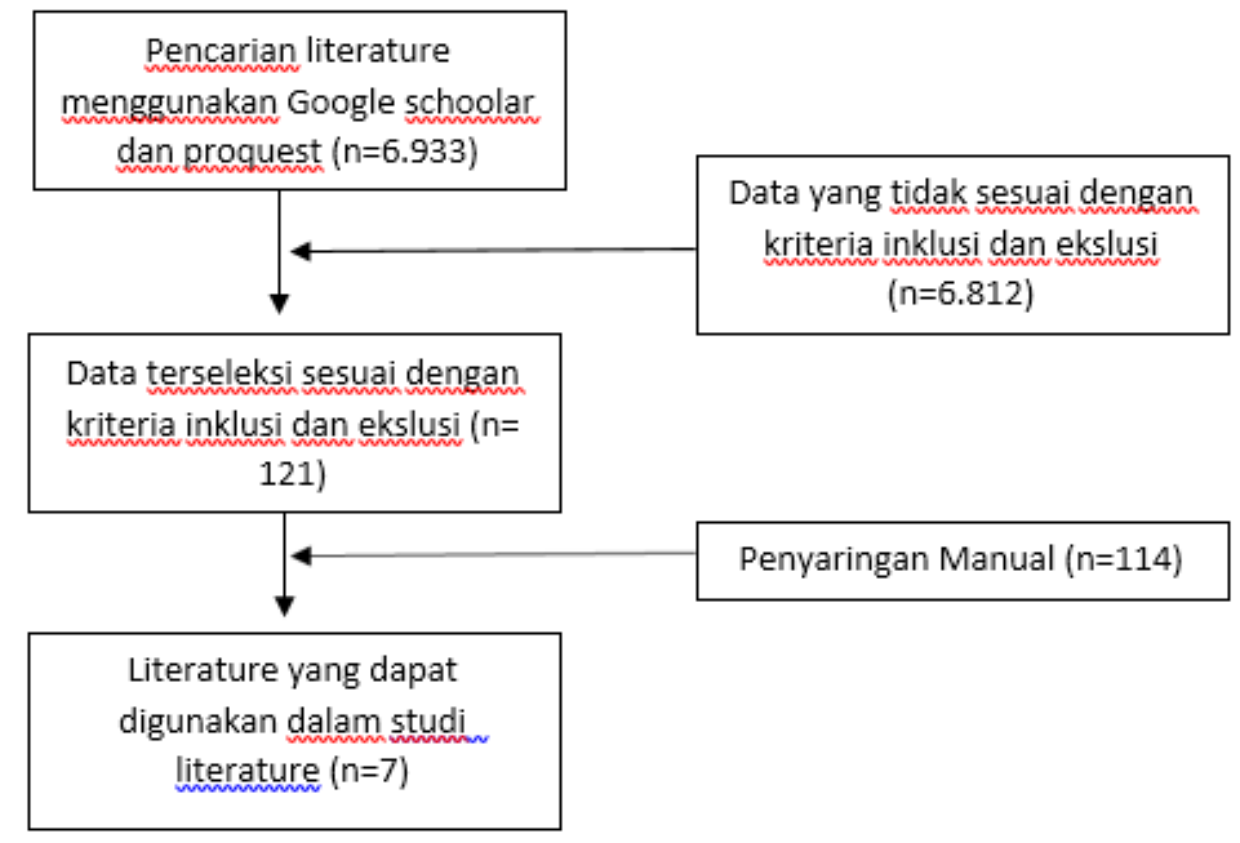

Gambar 1. Sistematika Pencarian Jurnal

\section{Hasil}

Dari hasil penyaringan artikel diperoleh tujuh artikel penelitain yang kemudian diolah menjadi sebuah tabel (Tabel 1).

Tabel 1. Hasil Pencarian Artikel Penelitian

\begin{tabular}{|c|c|c|c|c|c|c|}
\hline Penulis & $\begin{array}{c}\text { Nama } \\
\text { Tanaman } \\
\text { (Nama } \\
\text { ilmiah) }\end{array}$ & Komponen & Hewan coba & $\begin{array}{l}\text { Metode } \\
\text { Penelitian }\end{array}$ & Perlakuan dan dosis & Hasil \\
\hline $\begin{array}{c}\text { Ganeshkumar M, } \\
\text { Ponrasu T, Krithika } \\
\text { R, et al. }{ }^{14}\end{array}$ & $\begin{array}{c}\text { Tanaman } \\
\text { anting-anting } \\
\text { (Acalypha } \\
\text { indica) }\end{array}$ & Flavonoid & $\begin{array}{l}\text { Mencit } \\
\text { jantan } \\
(=12)\end{array}$ & $\begin{array}{l}\text { Uji klinis } \\
\text { dengan } \\
\text { melakukan } \\
\text { insisi pada } \\
\text { punggung } \\
\text { mencit jantan }\end{array}$ & $\begin{array}{l}\text { Mencit dibagi menjadi } 2 \\
\text { kelompok, kelompok } \\
\text { pertama diberikan } 200 \\
\text { ul ekstrak etanol } 50 \% \\
\text { daun Acalypha indica } \\
\text { (40 mg/kg bb) dan } \\
\text { kelompok kedua } \\
\text { diberikan larutan } \\
\text { Phosphate Buffered } \\
\text { Saline (PBS) }\end{array}$ & $\begin{array}{l}\text { Pada hari ke-12 luka } \\
\text { yang diobati dengan } \\
\text { acalypha indica sudah } \\
\text { menutup }>90 \% \\
\text { sedangkan kelompok } \\
\text { kontrol <80\%. } \\
\text { (p <0.05) }\end{array}$ \\
\hline $\begin{array}{c}\text { Kumarasamyraja D, } \\
\text { Swamivelmanickam } \\
\text { M. }^{15}\end{array}$ & $\begin{array}{c}\text { Tanaman } \\
\text { anting-anting } \\
\text { (Acalypha } \\
\text { indica) }\end{array}$ & Flavonoid & $\begin{array}{c}\text { Tikus } \\
\text { jantan atau } \\
\text { betina } \\
(\mathrm{n}=18)\end{array}$ & $\begin{array}{l}\text { Uji klinis } \\
\text { dengan } \\
\text { melakukan } \\
\text { insisi pada } \\
\text { punggung } \\
\text { tikus jantan } \\
\text { atau betina }\end{array}$ & $\begin{array}{l}\text { Mencil dibagi dalam } \\
\text { Tiga kelompok. } \\
\text { Kelompok pertama } \\
\text { tanpa pengobatan } \\
\text { sebagai kontrol negatif, } \\
\text { kelompok kedua } \\
\text { menggunakan povidione } \\
\text { iodine dan kelompok } \\
\text { ke-3 menggunakan } \\
\text { ekstrak aquades daun } \\
\text { anting-anting sebanyak } \\
1 \% \text {. }\end{array}$ & $\begin{array}{c}\text { Pada hari ke 3-19 } \\
\text { kelompok yang } \\
\text { diberikan povidione } \\
\text { iodine menunjukkan } \\
\text { persentase pengecilan } \\
\text { besar luka } 0,01436 \odot \\
0,0036 \text { dan kelompok } \\
\text { yang diberikan ekstrak } \\
\text { memiliki persentase } \\
\text { yang hampir sama } \\
(0,0126 \bullet 9,0028) \\
(\mathrm{p}<0.05)\end{array}$ \\
\hline $\begin{array}{c}\text { Garcia-Orue I, } \\
\text { Gainza G, Gutierrez } \\
\text { FB, et al. }{ }^{10}\end{array}$ & $\begin{array}{c}\text { Tanaman lidah } \\
\text { buaya (Aloe } \\
\text { vera) }\end{array}$ & Glukomanan & $\begin{array}{l}\text { Tikus } \\
\text { jantan } \\
(\mathrm{n}=20)\end{array}$ & $\begin{array}{l}\text { Uji klinis } \\
\text { dengan } \\
\text { melakukan } \\
\text { insisi pada } \\
\text { punggung } \\
\text { tikus jantan }\end{array}$ & $\begin{array}{c}5 \text { kelompok di mana } \\
\text { kelompok pertama tanpa } \\
\text { diobati, kelompok kedua } \\
\text { menggunakan } \\
\text { recombinant human } \\
\text { epidermal growth factor } \\
\text { (free EGF), kelompok } \\
\text { ketiga mendapat } \\
\text { kombinasi PLGA dan } \\
\text { gel aloe vera (PLGA- }\end{array}$ & $\begin{array}{c}\text { Pada hari ke } 8 \text {, luka } \\
\text { yang diberikan } \\
\text { nanofiber PLGA-AV- } \\
\text { EGF menunjukkan } \\
\text { persentase penutupan } \\
\text { luka }>50 \% \text { sedangkan } \\
\text { kelompok lain masih } \\
<50 \% \text {. } \\
(\mathrm{P}<0.05)\end{array}$ \\
\hline
\end{tabular}


AV), kelompok terakhir mendapat kombinas EGF, PLGA dan gel aloe vera (PLGA-AVEGF) dan kelompok 5 menggunakan nanofiber dari PLGA

\begin{tabular}{|c|c|c|c|c|}
\hline $\begin{array}{l}\text { Purohit SK, Solanki } \\
\text { R, Soni MK, et al. }{ }^{17}\end{array}$ & $\begin{array}{c}\text { Tanaman lidah } \\
\text { buaya (Aloe } \\
\text { vera) }\end{array}$ & Glukomanan & $\begin{array}{c}\text { Tikus } \\
\text { albino } \\
\text { dewasa } \\
\text { jantan } \\
\text { ataupun } \\
\text { betina } \\
(\mathrm{n}=18)\end{array}$ & $\begin{array}{l}\text { Uji klinis } \\
\text { dengan } \\
\text { melakukan } \\
\text { insisi pada } \\
\text { punggung } \\
\text { tikus albino } \\
\text { dewasa }\end{array}$ \\
\hline $\begin{array}{c}\text { Moerfiah, } \\
\text { Muztabadihardja, } \\
\text { Dewi S.P. }\end{array}$ & $\begin{array}{l}\text { Tanaman } \\
\text { pegagan } \\
\text { (Centella } \\
\text { asiatica) }\end{array}$ & $\begin{array}{c}\text { Saponin } \\
\text { Tripene acid }\end{array}$ & $\begin{array}{l}\text { Mencit } \\
\text { jantan } \\
(n=20)\end{array}$ & $\begin{array}{l}\text { Uji klinis } \\
\text { dengan } \\
\text { melakukan } \\
\text { insisi pada } \\
\text { punggung } \\
\text { leher mencit } \\
\text { jantan }\end{array}$ \\
\hline
\end{tabular}

\begin{tabular}{|c|c|c|c|c|}
\hline $\begin{array}{l}\text { Somboonwong J, } \\
\text { Kankaisre M, } \\
\text { Tantisira B, et al. }{ }^{19}\end{array}$ & $\begin{array}{l}\text { Tanaman } \\
\text { pegagan } \\
\text { (Centella } \\
\text { asiatica) }\end{array}$ & $\begin{array}{c}\text { Saponin } \\
\text { Tripene acid }\end{array}$ & $\begin{array}{c}\text { Tikus } \\
\text { jantan } \\
(\mathrm{n}=112)\end{array}$ & $\begin{array}{l}\text { Uji klinis } \\
\text { dengan } \\
\text { melakukan } \\
\text { insisi pada } \\
\text { punggung } \\
\text { leher tikus } \\
\text { jantan }\end{array}$ \\
\hline
\end{tabular}

\begin{tabular}{|c|c|c|c|c|}
\hline $\begin{array}{l}\text { Yao C.H, Yeh J.Y, } \\
\text { Chen Y.S, et al. }\end{array}$ & $\begin{array}{l}\text { Tanaman } \\
\text { pegagan } \\
\text { (Centella } \\
\text { asiatica) }\end{array}$ & $\begin{array}{c}\text { Saponin } \\
\text { Tripene acid }\end{array}$ & $\begin{array}{r}\text { Tikus } \\
\text { jantan }\end{array}$ & $\begin{array}{c}\text { Uji klinis } \\
\text { dengan } \\
\text { melakukan } \\
\text { insisi pada } \\
\text { punggung } \\
\text { leher tikus } \\
\text { jantan }\end{array}$ \\
\hline
\end{tabular}

gel aloe vera (2.5\%), tidak diobati dan diobati iodine

lima kelompok, yaitu; kelompok pertama diberikan salep dari ekstrak dengan basis minyak, kelompok kedua menggunakan salep dari ekstrak dengan basis emulsi, kelompok ketiga menggunakan salep berbasis laruta air, kelompok keempat menggunakan ekstrak murni dan kelompok kelima diberikan povidione iodine.

7 kelompok. Kelompok pertama tidak diobati, kelompok kedua menggunakan normal saline (NSS), kelompok ketiga menggunakan obat Tween $20 \AA$ sebagai kontrol positif, kelompok keempat menggunakan hexane extract (HexE) sebanyak 17.8 gr $(0.18 \%)$ kelompok kelima mengunakan ekstrak dengan ethyl acetate (EtAcE) sebanyak 32.7 gr $(0.33 \%)$, kelompok keenam menggunakan (MeE) dan kelompok ketujuh menggunakan ekstrak cair.

4 kelompok, kelompok pertama diberikan gelatin-poly(vinyl) alcohol, kelompok kedua diberikan electrospun gealtin membrane yang mengandung 31.2 $\mathrm{mg} / \mathrm{ml}$ ekstrak Centella asiatica, kelompok ke tiga hanya ditutup dengan kasa steril dan kelompok ke empat diberikan comfeel menggunakan povidione ekstrak dari methanol
Gel aloe vera pada hari ke-9 rata-rata besar lukanya $05.45 \pm 0.43$ $\left(\mathrm{mm}^{2}\right)$ lebih baik dari kelompok lainnya. $(\mathrm{p}<0.01)$

Kelompok yang diberikan ekstrak berupa salep dengan

basis minyak dan ekstrak utuh tidak sebaik povidione iodine. $(\mathrm{p}<0.05)$

Semua kelompok yang mendapat perlakuan dengan berbagai jenis ekstrak menunjukkan hasil penyembuhan luka yang lebih baik dibandingkan kontrol. $(\mathrm{p}<0.05)$

Ekstrak Centella asiatica lebih efektif dari pada kelompok lain. Pada pemeriksaan histopatologi tidak ditemukan adanya nekrosis fibrosis, edema dan sudah terbentuknya kembali folikel rambut. $(\mathrm{p}<0.05)$ 


\section{Pembahasan}

\section{Mekanisme Penyebuhan Luka}

Luka merupakan suatu kondisi di mana terjadi kerusakan pada jaringan baik kulit maupun jaringan lainnya. Luka dapat disebabkan oleh berbagai macam hal yang baik disengaja maupun tidak disengaja. Luka memiliki proses penyembuhan yang cukup kompleks dan dinamis. ${ }^{2,3}$ Lama proses penyembuhan luka tergantung dari jenis luka, besarnya luka, serta lamanya luka terjadi. Proses penyembuhan luka secara garis besar dibagi menjadi tiga fase, yaitu: hemostatis dan inflamasi, fase proliferasi, dan fase maturasi atau remodeling. ${ }^{3}$ Proses ini terjadi melalui mekanisme yang sangat kompleks dan dinamis. Namun, sejak dahulu kala masyarakat telah mengenal adanya tanaman herbal yang dapat digunakan untuk pengobatan tradisional. Terdapat beragam jenis tanaman yang dipercaya dan telah diteliti untuk memastikan efeknya. Beberapa contoh tanaman yang setelah diteliti dapat membantu proses penyembuhan luka, yaitu: Acaylpha indica, Aloe vera, Centella asiatica, Curcuma longa, dan masih banyak lagi. ${ }^{2,5}$

\section{Acalypha indica}

Acalypha indica atau anting-anting mengandung flavonoid yang dapat mempercepat proses penyembuhan luka kulit luar. Zat flavonoid ini telah diuji sebelumnya dengan cara isolasi dari tanaman Butea monosperma. Hasil isolasi dari flavonoid yang didapatkan dari tanaman tersebut kemudian diuji dan menunjukkan terjadi peningkatan kontraksi luka, pengurangan waktu epitelisasi dan peningkatan pembentukan jaringan granuloma. ${ }^{24}$ Efek flavonoid terhadap kontraksi luka dan epitelisasi diduga dapat meningkatkan migrasi sel dan proliferasi serta pembentukan, migrasi dan kerja myofibroblast. Peningkatan pembentukan jaringan granuloma pada luka disertai dengan peningkatan maturasi kolagen dan peningkatan protein merupakan salah satu indikator pertanda bahwa terjadi pembentukan jaringan baru. ${ }^{24,25}$

Ganeshkumar et al (2012) menggunakan ekstrak daun anting-anting sebanyak $200 \mu \mathrm{L}$ (40 $\mathrm{mg} / \mathrm{kgbb}$ ) dan dibandingkan dengan kontrol positif berupa larutan buffer yaitu phosphate buffered saline (PBS). Pada hari ke-12 didapatkan bahwa persentase penutupan luka pada kelompok Acalypha indica sudah lebih dari $90 \%$, sedangkan pada kelompok kontrol kurang dari $80 \%$. Pemeriksaan histopatologi didapatkan pada hari ke-14, kulit mencit yang menggunakan ekstrak daun anting-anting sudah menyelesaikan proses epitelisasi dengan kolagen padat yang telah tersusun rapi. Sedangkan pada kontrol positif lapisan epitel sudah terbentuk tetapi kolagennya masih lemah. Hasil penelitian ini didukung dengan penelitian oleh Kumarasamyraja (2015) yang menunjukkan hasil yang mirip dengan penelitian dengan Ganeshkumar (2012) di mana ekstrak daun anting-anting cukup efektif dalam membantu proses penyembuhan luka. Efek ekstrak daun anting-anting hampir sama dengan obat standar yaitu povidione iodine dilihat dari kontraksi penutupan luka yang baik. ${ }^{15}$

Percobaan in vivo dengan hewan percobaan membuktikan bahwa ekstrak etanol (50\%) daun anting-anting dapat mempercepat penyembuhan luka. Ekstrak tersebut dapat mempercepat proses penutupan luka lebih cepat dibandingkan larutan PBS. Dua makalah melaporkan bahwa ekstrak etanol $(50 \%)$ dan ekstrak aquades daun anting-anting cukup manjur (Ganeshkumar, 2012; dan Kusurasamyraja, 2015). Kemanjuran ekstrak daun anting-anting bisa disetarakan dengan kemanjuran povidine iodine yang merupakan obat yang sering digunakan.

\section{Aloe vera}

Aloe vera atau lidah buaya memiliki zat glukomanan yang terdapat pada bagian tengah tanaman. ${ }^{5,10}$ Bagian ini biasanya memiliki jaringan lendir yang dinamakan gel Aloe vera. Komponen glukomanan berdasarkan beberapa penelitian memberikan efek pada faktor pertumbuhan fibroblas dan menstimulasi aktivitas dan proliferasi fibroblas. Hal ini, menyebabkan terjadi peningkatan sekresi kolagen sel fibroblast. ${ }^{4,10}$ Selain itu juga terdapat komponen acemannan yang dilaporkan dapat mengurangi lama waktu penutupan luka pada kulit mencit. Pada penelitian yang dilakukan oleh Garcia Orue (2017), penelitian dilakukan dengan lebih kompleks yaitu menggabungkan gel aloe vera dengan polylacticco-glycolic acid (PLGA) serta recombinant human epidermal growth factor (free EGF).

Penilaian akhir penelitian ini dilihat dari kajian histopatologi yang menggunakan pewarna rutin $\mathrm{H} \&$ E. Preparat histopatologi yang dibuat pada hari ke 8 digunakan untuk membandingkan terjadinya re-epitelisasi, penyembuhan inflamasi dan deposit kolagen setiap kelompok. Hasil akhirnya didapatkan bahwa gabungan PLGA-AVEGF memiliki tingkat re-epitelisasi, penyembuhan inflamasi dan deposit kolagen yang lebih baik dibandingkan dengan kelompok lainnya. ${ }^{10}$ Penelitian lainnya dilakukan Purohit (2012) yang membandingkan gel Aloe vera $(2,5 \%)$ dan 
povidione iodie. Hasil menunjukkan pada hari ke9 terjadi peningkatan proses penyembuhan luka pada kelompok yang diberikan gel Aloe vera dibandingkan dengan kelompok lainnya. Hal ini dapat dilihat dari hasil uji statistik yang menunjukkan kelompok yang diberikan gel Aloe vera memiliki rata-rata besar luka sebesar $05.45 \pm 0.43 \mathrm{~mm}^{2}$ lebih kecil dibandingkan kelompok lain. ${ }^{11}$

Percobaan secara in vivo dengan penggunaan hewan percobaan menunjukkan bahwa gel Aloe vera dapat digunakan untuk penyembuhan luka. Hal ini ditunjukkan dari dua makalah (Garcia Orue. 2017 dan Purohit. 2012). Kedua makalah ini menunjukkan gel Aloe vera memiliki kandungan yang dapat mempercepat waktu reepitelisasi dan penutupan luka. Kemanjuran dari gel aloe vera bahkan lebih baik dibandingkan dengan povidione iodine.

\section{Centella asiatica}

Centella asiatica atau tanaman pegagan dapat digunakan untuk proses penyembuhan luka seperti luka kronik misalnya ulkus diabetikum dan menurunkan pembentukan scar. ${ }^{2,19}$ Tanaman pegagan mengandung saponin. Saponin mengandung asam tripen yang terdiri dari asiatic acid, madecassic acid dan asiatiscoside ditambah dengan gugus gula ester. Komponen tripene acid dapat menstimulasi sintesis kolagen pada sel fibroblas secara in vitro. Komponen asiatiscoside memegang peran paling utama, karena komponen ini menstimulasi proliferasi sel fibroblas dan mengurangi terbentuknya scar (bekas luka). Asiatiscoside bekerja dengan cara meningkatkan proliferasi sel fibroblas dan sintesis matriks ekstraseluler. ${ }^{18,19}$

Percobaan secara in vivo dengan penggunaan hewan percobaan menunjukkan bahwa ekstrak non polar dari Centella asiatica dapat digunakan untuk penyembuhan luka. Tiga makalah membahas kemanjuran Centella asiatica tersebut ( Chun et al. 2014, Moerfiah, 2014 dan Somboonwong, 2012).

Penelitian mengenai tanaman pegagan dilakukan oleh Chun et al. (2014), yaitu dengan menggunakan metode electrospinning untuk menghasilkan serat. Penelitian dilakukan pada tikus jantan selama 14 hari. Pengamatan histopatologi dengan pewarnaan masson's trichome memperlihatkan kelompok $\mathrm{B}$ memiliki warna biru yang mendominasi dibandingkan kelompok lainnya. Hal ini menandakan bahwa terjadi deposit kolagen yang lebih banyak dibandingkan kelompok lainnya. Sediaan kulit dengan pewarnaan $H \& E$ memperlihatkan sel basal pada kelompok A, B dan D memiliki bentuk reguler sehingga membantu proses penyembuhan luka.

Penelitian yang dilakukan oleh Moerfiah pada tahun 2014 menunjukkan bahwa kelompok yang diberikan salep berbahan ekstrak dengan minyak dan povidione iodine memiliki hasil yang sangat baik dibandingkan kelompok lain. Namun berdasarkan analisa lebih lanjut didapatkan bahwa salep berbahan dasar minyak dan ekstrak murni tidak sebaik povidione iodine untuk mempercepat proses penyembuhan luka. ${ }^{18}$

Penelitian lainnya dilakukan oleh Somboonwong (2012) tentang efek ekstrak Centella asiatica terhadap luka bakar. Pada hari ke-10 didapatkan hasil bahwa kelompok yang diobati dengan hexane extract dan etyhl acetate ectract mengalami perbaikan yang signifikan dibandingkan kelompok lainnya, bahkan dari kelompok kontrol positif. ${ }^{19}$ Pada pemeriksaan histopatologi di hari ke-14, kelompok yang diberikan gelatin-poly(vinyl) alcohol mengalami nekrosis fibrinoid yang menonjol pada lapisan sub-epidermis, ditandai dengan permeasi kolagen dengan fibrin dan perubahan degeneratif. Proses re-epitelisasi tidak selesai dengan adanya eksudat pada permukaan kulit. Pada kelompok yang diobati dengan NSS dan Tween $20^{\circledR}$ didapatkan nekrosis fibrinoid pada beberapa bagian dan rongga kosong yang menandakan terjadinya edema. Pada kelompok ini didapatkan pula proses reepitelisasi masih belum selesai dan kelompok yang diobati dengan NSS lebih baik dibandingkan dengan Tween $20^{\circledR}$. Sedangkan kelompok yang diberi perlakuan ekstrak dengan berbagai metode menunjukkan hasil telah selesainya proses epitelisasi dan keratinisasi tanpa adanya nekrosis atau inflamasi. ${ }^{19}$

\section{Simpulan}

Berdasarkan hasil studi literatur dari beberapa penelitian yang telah dilakukan. Ekstrak tanaman Acalypha indica, Aloe vera dan Centella asiatica dapat digunakan untuk membantu proses penyembuhan luka pada kulit. Penggunaan ekstrak dari ketiga tanaman ini menunjukkan hasil penyembuhan dengan kemanjuran sebanding dengan obat sintetis.

\section{Saran}

Disarankan agar dikembangkan sediaan obat herbal dari ketiga tanaman tersebut, agar dapat tersedia dan dapat digunakan dengan segera, misal dalam bentuk gel atau salep atau spray, aplikasi teknologi enkapsulasi, liposom, dan nano perlu dicoba. Tetapi, diperlukan clinical trial untuk 
memastikan keamanan dan kemanjuran dari obat herbal dari ketiga tanaman tersebut.

\section{Daftar Pustaka}

1. Menaldi SL, et al. Ilmu penyakit kulit dan kelamin. edisi 7. Jakarta: FKUI; 2011. H.3-6.

2. Nurfiah, Tahir T, Yusuf S. Aktivitas zat aktif berbasis tanaman tradisional Indonesia dalam penyembuhan luka. Jurnal Keperawatan Muhammadiyah Surabaya. 2019;4(1):74-80.

3. Novyana RM, Susianti. Lidah buaya (Aloe vera) untuk penyembuhan luka. Majority. 2016;5:149-53.

4. Dan MM, Sarmah P, Rao Vana D, et al. Wound healing: concepts and updates in herbal medicine. Int $\mathrm{J}$ Med Res Heal Sci. 2018;7(1):170-81.

5. Saini S, Dhiman A, Nanda S. Traditional indian medicinal plants with potential wound healing activity: a review. Int J Pharm Sci Res 1809 IJPSR. 2016;7(5):1809-19.

6. Oktaviani DJ, Widiyastuti S, Maharani DA, et al. Review: bahan alami penyembuh luka. Farmasetika. 2019;4(3):44.

7. Anggraeni L, Bratadiredja MA. Tanaman obat yang memilki aktivitas terhadap luka bakar. Farmaka Universitas Padjadjaran. 2018;16(2):222-30.

8. Kumar V, Abbas AK, Aster JC. Radang dan pemulihan jaringan. Robbins Basic Pathology. $9^{\text {th }}$ ed. Elsevier;2012. p.70-2.

9. Purnama H, Sriwidodo, Ratnawulan S. Review sistematik: proses penyembuhan dan perawatan luka. Farmaka. 2016;15(2):251-7.

10. Garcia-Orue I, Gainza G, Gutierrez FB, et al. Novel nanofibrous dressings containing rhEGF and Aloe vera for wound healing applications. Int J Pharm. 2017;523(2):55666.

11. Maver T, Maver U, Stana KK, et al. A review of herbal medicines in wound healing. Int $\mathbf{J}$ Dermatol. 2015;54(7):740-51.

12. Kirom HS, Ramadhania ZM. Review artikel: aktivitas biologis tanaman kucing-kucingan. Fakultas Farmasi Universitas Padjajaran. 2016;15(3):1-13.

13. Chekuri S, Jyoti A, Sompaga S, Panjala S, et $a l$. Evaluation of anti microbial and anti fungal activity of Acalypha indica 1., leaf extract. Int J Pharmacogn Phytochem Res. 2018;10(01):48-51.

14. Ganeshkumar M, Ponrasu T, Krithika R, et al. Topical application of Acalypha indica accelerates rat cutaneous wound healing by upregulating the expression of Type I and III collagen. J Ethnopharmacol. 2012;142(1):1422.

15. Kumarasamyraja D, Swamivelmanickam M. Evaluation of in vivo and in vitro wound healing activity of aqueous extract of Acalypha indica. Int Res J Pharm. 2015;6(1):57-61.

16. Jagatheeswari D, Deepa J, Ali HS, et al. Acalypha indica L-an important medicinal plant: a review of its traditional uses, and pharmacological properties. Int J. 2013; 3(2009):19-22.

17. Purohit SK, Solanki R, Soni MK, et al. Evaluation of aloe vera leaves pulp as topical medicament on wound healing. IJPR. 2012;2(3):110-2.

18. Moerfiah, Muztabadihardja, Dewi SP. Efektivitas sediaan salep ekstrak herba pegagan (Centella asiatica (L) Urb) untuk penyembuhan luka pada mencit jantaan (Mus musculus albinus). Fitofarmaka. 2014;4(1):2733.

19. Somboonwong J, Kankaisre M, Tantisira B, et $a l$. Wound healing activities of different extracts of Centella asiatica in incision and burn wound models: an experimental animal study. BMC Complement Altern Med. 2012;12.

20. Yao CH, Yeh JY, Chen YS, et al. Wound healing effect of electrospectrun gelatin nanofibers containing Centella asiatica extract in a rat model. J Tissue Eng Regen Med. 2015.

21. Nurdiantini I, Prastiwi S, Nurmaningsari T. Perbedaan efek penggunaan povidone iodine $10 \%$ dengan minyak zaitun terhadap penyembuhan luka robek (lacerated wound). $\mathbf{J}$ Nurs News. 2016;2(1):511-23.

22. Bigliardi PL, Alsagoff SAL, El-Kafrawi HY, et al. Povidone iodine in wound healing: A review of current concepts and practices. Int $\mathbf{J}$ Surg. 2017;44:260-8.

23. Pricilia DD, Saptarini NM. Teknil isolasi dan identifikasi kurkumonoid dalam Curcuma longa. Fakultas Farmasi Universitas Padjajaran. 2016;4:1-13.

24. Avula M, Babu KS, Sankar TR, et al. Wound healing activity of flavonoid fraction isolated from the stem bark of Butea monosperma (Lam) in albino Wistar rats. EuroJ ExpBio. 2013;3:1-6.

25. Aslam MS, Ahmad MS, Riaz H, et al. Role of flavonoids as wound healing agent. Phytochem-Source Antioxidants Role Dis Prev. 2018. 